\title{
Response of Selected Plant Species Seeded on Mule Deer Winter Range
}

\author{
DONAVIN A. LECKENBY AND DALE E. TOWEILL
}

\begin{abstract}
A selection of 13 bunchgrasses, 4 legumes, and 2 shrubs were planted in 2 seasons in 5 plant communities within the sagebrushbunchgrass and juniper zones of the Fort Rock mule herd winter range in south-central Oregon. Rate of establishment averaged $3.9 \%$ for all planted species, and it was generally dependent on seeding rate, season, and plant community. Standard crested wheatgrass, Siberian wheatgrass, smooth brome, hard fescue, and antelope bitterbrush established better when planted in the fall. Intermediate wheatgrass, streambank wheatgrass, Ladak alfalfa, and hairy vetch established better when planted in the spring. From 31 to $3 \%$ of the plants of standard crested wheatgrass, Siberian wheatgrass, pubescent wheatgrass, hard fescue, and antelope bitterbrush survived to the sixth growing season. Standard crested wheatgrass, Siberian wheatgrass, and pubescent wheatgrass survived best in the juniper/big sagebrush-antelope bitterbrush community, but antelope bitterbrush survived at a slightly higher rate in the juniper/antelope bitterbrush-big sagebrush community.
\end{abstract}

Shortages of forage for livestock and mule deer (Odocoileus hemionus hemionus) in eastern Oregon have increasingly resulted in cooperative programs between range and wildlife managers for range improvement (Game Division 1967, 1968, 1969). Involved agencies planned winter range rehabilitation projects relying on methods perfected in Utah (Plummer et al. 1968) for planting browse, forbs, and grasses. Seedings of exotic wheatgrasses (Agropyron cristatum, $A$. desertorum, $A$. sibericum) had been established locally in south-central Oregon and were grazed by mule deer (Leckenby 1968). Establishment of other grasses, forbs, and shrubs could provide a diversity of forage available in fall, winter, and spring, but the adaptability of such species to low-productivity sites in the sagebrush-bunchgrass and juniper zones was unknown. This study was the initial phase of a research project designed to help determine which species to plant and how to best design and implement rehabilitation of depleted winter ranges for benefit to mule deer. Seeds of 13 exotic grasses, 4 exotic legumes, 1 exotic shrub, and 1 native shrub were tested in 5 native plant communities. Emergence and survival of species was documented for six growing seasons, 1969-1974.

\section{Study Area}

Test seeding plots were established within the Fort Rock mule deer winter range in Lake County, Oregon, at $121^{\circ} 07^{\prime} 30^{\prime \prime}$ west longitude and between $43^{\circ} 07^{\prime}$ and $43^{\circ} 15^{\prime}$ north latitude, $3-10 \mathrm{~km}$ (2-6 mi) northwest of the settlement of Silver Lake. The climate was cool and semiarid to subhumid, with cold winters, warm

Leckenby is a biologist with the Oregon Department of Fish and Wildlife's Research and Development Section, stationed at La Grande, Oregon, and Toweill is currently pursuing a Ph.D. in the Department of Fisheries and Wildlife, Oregon State University. We thank A.W. Adams, W.E. Olson, L.D. Conn, D.A. Koehler, R.W. Roberts, and B.T. Ferry of the Oregon Department of Fish and Wildlife for assistance during this study, and especially thank J.L. Schwendiman, both for providing materials that were used in the plantings and for his suggestions on species to be tested.

This research project is primarily financed by Federal Aid to Wildlife Restoration funds under P.R. Project W-70-R. summers, and a short frost-free season (Hampton 1964, State Water Resources Board 1969, Pacific Northwest River Basins Commission 1969a and 1969b). Most of the annual precipitation which averaged $20-25 \mathrm{~cm}(8-10$ in) occurred from November through June. Snowfall ranged from 63 to $127 \mathrm{~cm}(25-50 \mathrm{in})$; most fell in January (Pacific Northwest River Basins Commission $1969 \mathrm{c})$. Broad daily and annual ranges in temperature were common, and there was a $50 \%$ probability of frost on or after $19 \mathrm{July}$ and prior to 10 August annually (Eichhorn et al. 1961).

The prominent shrub-steppe and juniper woodland associations were broadly correlated with soil and moisture conditions (Franklin and Dyrness 1973). Provisional vegetation types (plant communities) in this area have been identified by Schallig (1971) and were similar to those described by others for central and eastern Oregon and eastern Washington (Eckert 1958, Driscoll 1962 and 1964, Dyrness and Youngberg 1966, Daubenmire and Daubenmire 1968, Daubenmire 1970, Dealy 1971, Franklin and Dyrness 1973).

The area was a winter range for mule deer of the Fort Rock herd. We estimated deer densities were between 27 and $43 \mathrm{deer} / \mathrm{km}^{2}(70$ to $\left.110 / \mathrm{mi}^{2}\right)$.

\section{Methods}

Nineteen species of plants were selected for test seeding. Species selected, their scientific names, seed variety names, and seeding rates are shown in Table 1. Seeding rates employed (lb seed/acre) were usually increased above recommended seeding rates (Hafenrichter et al. 1968) to better control invading cheatgrass (Bromus tectorum) and rabbitbrush (Chrysothamnus spp.) and to minimize the time required to develop satisfactory stands (Hull and Klomp 1967).

Test plots were established in plant community stands common to mule deer winter range in south-central Oregon (see Schallig 1971). Five plant communities were selected: (1) a silver sagebrush/Newberry cinquefoil/Richardson's muhly-Baltic rushsedge (Artemisia cana/Potentilla newberryi/Muhlenbergia richardsonis-Juncus balticus-Carex) community (hereafter referred to as a silver sagebrush basin), (2) a lanceleaf green rabbitbrush-mountain big sagebrush/western needlegrassbottlebrush squirreltail-cheatgrass brome (Chrysothamnus viscidiflorus lanceolatus-Artemisia tridentata vaseyana/Stipa occidentalis-Sitanion hystrix-Bromus tectorum) community (referred to as a green rabbitbrush-big sagebrush flat), (3) a western juniper/mountain big sagebrush/western needlegrass (Juniperus occidentalis/Artemisia tridentata vaseyana/Stipa occidentalis) community (referred to as the juniper/big sagebrush/western needlegrass community), (4) a western juniper/mountain big sagebrush-antelope bitterbrush/Thurber needlegrass-Idaho fescue-bottlebrush squirreltail-bearded bluebunch wheatgrass (Juniperus accidentalis/Artemisia tridentata vaseyana-Purshia tridentata / Stipa thurberiana-Festuca idahoensis-Sitanion hystrix-Agropyron spicatum) community (hereafter referred to as the juniper/big sagebrush-antelope bitterbrush community), and (5) a western juniper/antelope bitterbrush-mountain big sage- 


\begin{tabular}{|c|c|c|c|c|}
\hline \multirow[b]{2}{*}{ Plant species } & \multirow[b]{2}{*}{ Scientific name } & \multirow[b]{2}{*}{ Varietyl } & \multicolumn{2}{|c|}{ Seeding rate } \\
\hline & & & lb/acre & Seeds per lineal foot \\
\hline Standard crested wheatgrass & Agropyron desertorum & Nordan & 16 & 62 \\
\hline Fairway crested wheatgrass & Agropyron cristatum & Fairway & 16 & 70 \\
\hline Tall whcatgrass & Agropyron elongatum & Alkar & 18 & 31 \\
\hline Intermediate wheatgrass & Agropyron intermedium & Greenar & 18 & 40 \\
\hline Streambank wheatgrass & Agropyron riparium & Sodar & 20 & 75 \\
\hline Siberian wheatgrass & Agropyron sibiricum & P-27 & 16 & 88 \\
\hline Pubescent wheatgrass & Agropyron trichophorum & Topar & 24 & 48 \\
\hline Smooth brome & Bromus inermis & Manchar & 18 & 51 \\
\hline Blue wildrye & Elymus glaucus & P-2662 & 20 & 58 \\
\hline Russian wildrye & Elymus junceus & P-9012 & 16 & 60 \\
\hline Hard fescue & Festuca ovina duriuscula & Durar & 48 & 592 \\
\hline Big bluegrass & Poa ampla & Sherman & 16 & 308 \\
\hline Indian ricegrass & Oryzopsis hymenoides & - & 46 & 25 \\
\hline Chickpea milkvetch & Astragalus cicer & Cicar & 25 & 80 \\
\hline Alfalfa & Medicago sativa & Ladak & 30 & 148 \\
\hline Sainfoin & Onobrychis viciaefolia & Onar & 20 & 8 \\
\hline Hairy vetch & Vicia villosa & - & 45 & 20 \\
\hline Fourwing saltbush & Atriplex canescens & - & 30 & 36 \\
\hline Antelope bitterbrush ${ }^{2}$ & Purshia tridentata & - & 12 & 5 \\
\hline
\end{tabular}

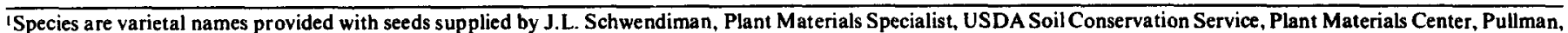
Wash.

2Hand planted.

brush/bearded bluebunch wheatgrass-Idaho fescue-Thurber needlegrass (Juniperus occidentalis/Purshia tridentata-Artemisia tridentata vaseyana/Agropyron spicatum-Festuca idahoensisStipa thurberiana) community (referred to as the juniper/antelope bitterbrush-mountain big sagebrush community). Plant names follow Garrison et al. (1976).

Five community stands selected on the Ward Lake study area were paired with similar community stands on the Nine Mile Ridge study area. Paired plant community stands were replications selected to be as similar as possible in terms of plant species composition, relative species abundance, elevation, and soil type.

A test plot was established within each of the 10 stands. Test plots measured 15.3 by $7.3 \mathrm{~m}(50$ by $24 \mathrm{ft})$ and were fenced to prevent grazing by cattle (Bos taurus), black-tailed jackrabbits (Lepus californicus), or mountain cottontail rabbits (Sylvilagus nuttallii). Seedbeds were prepared by first removing all western juniper trees then by repeated raking with a spring-toothed harrow to a depth of approximately $20 \mathrm{~cm}(8 \mathrm{in})$, until the soil in each site was well tilled and no preexisting plants remained. (Juniper stumps and roots were not removed from the juniper/antelope bitterbrush-big sagebrush stands nor were these plots fenced.) In the spring, one-quarter of each plot was treated with urea fertilizer (45\% nitrogen) applied at a rate of $26 \mathrm{~kg} / \mathrm{ha}(142 \mathrm{lb} / \mathrm{acre})$, onequarter was treated with a nitrogen-phosphorus-potassium (NPK) fertilizer ( $23 \%$ nitrogen) applied at a rate of $53 \mathrm{~kg} / \mathrm{ha}(287 \mathrm{lb} /$ acre $)$, and the remaining one-half of each plot was not fertilized. The rate of nitrogen application on both fertilized portions of each plot was $12 \mathrm{~kg} /$ ha $(66 \mathrm{lb} /$ acre $)$.

Species were planted in particular communities according to their expected adaptability to the site indicated by a given plant community. All species except antelope bitterbrush were mechanically planted at a calibrated seeding rate (seeds per lineal foot) in rows $30.5 \mathrm{~cm}(1 \mathrm{ft})$ apart extending the full length of each plot. The legumes were mixed with their specific mycorrhizal innoculants during seeding. Antelope bitterbrush was hand planted at a depth of $2.5 \mathrm{~cm}$ ( 1 inch). One-half of each plot was seeded with its full complement of species in fall 1968; the remainder was seeded with the full complement of species in spring 1969. Each replicate plant community stand was seeded with the same species and at the same rate as its counterpart.

All plants of the test species that emerged and survived in 2 rand omly selected $30.5 \mathrm{~cm}^{2}\left(1 \mathrm{ft}^{2}\right)$ permanent subplots within each treatment were counted.
Raw data comprised the summed count of plants emerging or surviving in the two subplots within each treatment. Statistical analysis with the non-parametric Kruskal-Wallis one-way analysis of variance by ranks and the Wilcoxon matched-pairs signed-ranks test compared emergence, establishment, and survival of planted species by season of planting, fertilization treatment, plant community, and replicate area (Siegel 1956).

\section{Results and Discussion}

\section{Emergence}

Emergence rates, calculated as the percentage of seeds planted which produced an emergent plant, in July 1969 varied from 13.9 to $0.1 \%$ and averaged $4.7 \%$ for all species (Table 2). Emergence rates appeared dependent on seeding rate.

Rate of emergence for the 7 wheat grass varieties tested averaged $5.2 \%$, and ranged from $8.8 \%$ to $2.0 \%$ (Table 2 ). These rates were lower than those reported by Cook ct al. (1967) for 4 wheatgrass species seeded in similar habitat in Utah. In that study, average emergence for crested wheatgrass was $4.1 \%$ (lower than the emergence rate for standard crested wheatgrass in this study, but higher than the rate of Fairway crested wheatgrass); emergence rates for tall wheatgrass, intermediate wheatgrass, and pubescent wheatgrass reported by them $(9.5 \%, 10.5 \%$, and $10.8 \%$, respectively) were all higher than emergence rates recorded in this study. Similarly, Hull (1974) reported a July emergence rate for intermediate wheatgrass of $35.7 \%$.

Almost no emergence was recorded for big bluegrass or Indian ricegrass in this study.

Sainfoin emerged at a higher rate than any of the other legumes tested (Table 2).

Of the 2 shrub species tested, hand-planted antelope bitterbrush emerged at the highest rate recorded for any species tested (13.9\%) while almost no emergence of fourwing saltbush occurred $(0.2 \%)$.

\section{First-year Establishment}

Establishment at the end of the first growing season was generally slightly lower than July emergence rates (Table 2) and averaged $3.9 \%$ over all species. Frischknecht (1951) reported that 5-7\% of the planted seeds produced established plants on a sagebrush site in Utah, and that $16-22 \%$ produced established plants on a mountain brush site.

First-year establishment rates of pubescent wheatgrass, Siberian 
Table 2. Overall rates of emergence in the first growing season (measured July 1969), establishment in the first year (measured September 1969), and survival through the sixth year (measured September 1974) of each of the plant species and varieties tested, expressed as a percentage of seeds plants.

\begin{tabular}{|c|c|c|c|c|}
\hline Plant species & Variety & Percent emergence & Percent establishment & Percent survival \\
\hline Standard crested wheatgrass & Nordan & 7.9 & 6.8 & 0.8 \\
\hline Fairway crested wheatgrass & Fairway & 2.0 & 1.6 & 0.1 \\
\hline Tall wheatgrass & Alkar & 2.5 & 1.2 & - \\
\hline Intermediate wheatgrass & Greenar & 5.8 & 4.8 & 0.2 \\
\hline Streambank wheatgrass & Sodar & 3.7 & 2.6 & - \\
\hline Siberian wheatgrass & P-27 & 5.7 & 5.8 & 0.8 \\
\hline Pubescent wheatgrass & Topar & 8.8 & 9.6 & 0.3 \\
\hline Smooth brome & Manchar & 5.9 & 5.9 & $T^{\prime}$ \\
\hline Blue wildrye & P-2662 & 2.4 & 1.5 & $T^{\prime}$ \\
\hline Russian wildrye & P-9012 & 2.4 & 1.7 & 0.2 \\
\hline Hard Fescue & Durar & 3.7 & 2.6 & 0.1 \\
\hline Big bluegrass & Sherman & 0.1 & $T^{\prime}$ & - \\
\hline Indian ricegrass & - & 0.3 & - & - \\
\hline Chickpea milkvetch & Cicar & 2.6 & 1.0 & $\mathbf{T}^{1}$ \\
\hline Alfalfa & Ladak & 3.0 & 2.9 & $\mathrm{~T}^{\prime}$ \\
\hline Sainfoin & Onar & 11.8 & 4.0 & - \\
\hline Hairy vetch & - & 7.3 & 7.5 & - \\
\hline Fourwing saltbush & - & 0.2 & 0.3 & - \\
\hline Antelope bitterbrush & - & 13.9 & 13.4 & 2.2 \\
\hline
\end{tabular}

ITrace-less than or equal to $0.05 \%$.

wheatgrass, hairy vetch, and fourwing saltbush increased slightly above emergence rates calculated in July, perhaps due to later emergence or difficulty in counting small emergent plants. Chickpea milkvetch and sainfoin declined dramatically in numbers between July and September.

Rate of establishment between replicates of the same plant community did not differ significantly for any species except Siberian wheatgrass. Siberian wheatgrass established at a greater rate $(p \leq 0.05)$ in the Nine Mile Ridge replicate of the juniper/big sagebrush-antelope bitterbrush community than in the Ward Lake replicate. The same results were obtained in later treatments in the former area (Roberts 1975) and at Ward Lake (Leckenby and Toweill 1978).

In the silver sagebrush basins, Fairway crested wheatgrass, intermediate wheatgrass, streambank wheatgrass, pubescent wheatgrass, alfalfa, and hairy vetch all established at greater rates than tall wheatgrass and chickpea milkvetch. These differences were not consistent with differences in seeding rate.

On the green rabbitbrush-big sagebrush flats, alfalfa establishment in the first year was greater than that of any other species, while intermediate wheatgrass and hairy vetch establishment exceeded that of Fairway crested wheatgrass, tall wheatgrass, blue wildrye, chickpea milkvetch, and sainfoin. Streambank wheatgrass plants established in greater numbers than tall wheatgrass, chickpea milkvetch, and sainfoin. Differences in establishment during the first year were, again, not consistent with differences between seeding rates.

In the juniper/big sagebrush/western needlegrass community, standard crested wheatgrass and Siberian wheatgrass established in greater numbers than any other species; establishment of blue wildrye exceeded Russian wildrye and smooth brome in this community although their seeding rates were similar (Table 1 and Table 2). Sainfoin was the least successful species seeded on this site.

In the juniper/big sagebrush-antelope bitterbrush community, establishment of hard fescue exceeded that of all other species, while standard crested, Siberian, and pubescent wheatgrasses all established in significantly greater numbers than Russian wildrye. Alfalfa established* in significantly greater numbers than either chickpea milkvetch or sainfoin.

Establishment of most species tested was different between fall and spring plantings. Standard crested wheatgrass, Siberian wheatgrass, smooth brome, hard fescue, and antelope bitterbrush responded significantly better to fall seeding, whereas intermediate wheatgrass, streambank wheatgrass, alfalfa, and hairy vetch responded better to spring seeding. Establishment rates of Fairway crested wheatgrass, pubescent wheatgrass, blue wildrye, Russian wildrye, and chickpea milkvetch were not significantly different between seasons.

Our findings compare with grass seeding result variations reported elsewhere. Standard crested wheatgrass responded best to fall planting in north-central Arizona (Lavin et al. 1973). Spring plantings of Fairway crested wheatgrass in Utah produced the greatest emergence rates (Cook et al. 1967), and crested wheatgrass responded most favorably to spring planting in Colorado, although fall seedings were frequently successful (McGinnies 1960). Intermediate wheatgrass was found to emerge best when summer seeded in southeastern Idaho, although fall seedings were also successful (Hull 1948, 1974); Cook et al. (1967) reported that best results occurred when this species was spring seeded. Pubescent wheatgrass responded best to spring seeding in Utah (Cook et al. 1967). Russian wildrye did not respond significantly to either season of seeding in Utah (Drawe et al. 1975).

Schwendiman (1955) recommended that mixtures containing legume seeds should be planted in spring, since fall-germinated legumes are more susceptible to freezing damage than are grasses. Of the 4 legumes tested in this study, alfalfa and hairy vetch responded best to spring seeding.

Plummer et al. (1968) concluded that fall planting of most shrubs is beneficial in that it overcomes dormancy, promotes rapid spring growth through vernalization, results in larger seedlings able to respond to the earliest favorable spring conditions for growth, and effectively reduces seed loss to rodents. In our tests, antelope bitterbrush emerged best from fall plantings. Others reported that antelope bitterbrush responded better to spring seeding in northern California (Woolfolk 1959 and 1961, Hubbard 1960, Hubbard and Sanderson 1961).

Species tested in this study did not respond significantly to any of the fertilizer treatments.

\section{Survival}

Only $S$ of the 19 species tested survived to the sixth growing season. The numbers of the survivors-standard crested wheatgrass, Siberian wheatgrass, pubescent wheatgrass, hard fescue, and antelope bitterbrush-declined throughout the 6 growing seasons, although individual plants appeared well established. Standard crested wheatgrass, Siberian wheatgrass, and antelope bitterbrush survived in the greatest numbers-13,31, and $16 \%$, respectively, of the number of emergent plants. Corresponding figures were $3 \%$ for pubescent wheatgrass and $4 \%$ for hard fescue. 
All of the above 5 species survived in the juniper/big sagebrushantelope bitterbrush community. The wheatgrasses survived better in that community than in any other in which they were planted, but hard fescue was planted in no other community. Antelope bitterbrush survived at only a slightly higher rate in the unprotected juniper/antelope bitterbrush-big sagebrush stands and the shrubs were more intensively browsed there than those were in the fenced juniper/big sagebrush-antelope bitterbrush stands. Average sizes of shrubs were greater in the fenced plots than in the unfenced plots, $35 \mathrm{~cm}$ ( 14 inch) height and $25 \mathrm{~cm}$ ( 10 inch) crown diameter vs. $20 \mathrm{~cm}(8$ inch) and $15 \mathrm{~cm}(6 \mathrm{inch})$, respectively.

All legumes failed to survive despite innoculation with their species-specific mycorrhizae. Ladak alfalfa persisted the longest, lasting through the end of the third growing season. Chickpea milkvetch survived to the end of the second season, but hairy vetch (an annual) did not reseed and failed to survive beyond the first growing season.

Tall wheatgrass, streambank wheatgrass, and big bluegrass did not survive beyond the second growing season.

Three of the four grass species that persisted through the sixth growing season (standard crested wheatgrass, Siberian wheatgrass, and hard fescue) and antelope bitterbrush were among the species that emerged in significantly greater numbers when fall seeded.

\section{Conclusions}

Emergence rates of plant species tested in this study were dependent on seeding rates. Emergence averaged $8 \%$ of the seeding rate over all species, ranging from 0 to $40 \%$. Emergence rates did not differ significantly among plant community replicates, indicating that the level of community identification was sufficiently precise to minimize site effects on emergence. Species emergence rates differed consistently between plant community treatments in each study area.

Emergence rates for most species differed among seasons of planting. Most grasses responded best to fall seeding, legumes to spring seeding, and antelope bitterbrush to fall seeding.

Emergence rates were not detectably affected by any of the fertilizer treatments tested.

Only 5 of the 19 species tested survived through the sixth growing season-standard crested wheatgrass, Siberian wheatgrass, pubescent wheatgrass, hard fescue, and antelope bitterbrush. Survival was greatest in the juniper/big sagebrush-antelope bitterbrush sites. Of the five surviving plant species, the best 4 had shown greater relative emergence from fall plantings than from spring plantings.

Results of this study suggest that seed mixtures generally recommended and used in rehabilitation of sagebrush-bunchgrass and juniper winter ranges of mule deer establish stands of only exotic wheatgrasses. Results were similar for larger projects in such plant communities in eastern Oregon (Game Division 1968; Roberts 1975a, 1975b; Leckenby and Toweill 1978). Unless benefits from short-term survival can be demonstrated, expense and planning required to include other grasses, forbs, and saltbush in range seed mixtures would be more effectively applied in evaluation of project benefits to livestock and wildlife. A diversity of seeded plants would likely provide succulent forage for longer periods during the livestock and deer use seasons, but survival from usually applied seed mixtures has not attained such a desirable objective.

\section{Literature Cited}

Cook, C.W., L.A. Stoddart, and P.L. Sims. 1967. Effects of season, spacing, and intensity of seeding on the development of foothill range grass stands. Utah State Agr. Exp. Sta. Bull. Utah State Univ.

Daubenmire, R. 1970. Steppe vegetation of Washington. Washington Agr. Exp. Sta. Tech. Bull. 62. Washington State Univ.

Daubenmire, R., and J.B. Daubenmire. 1968. Forest vegetation of eastern Washington and northern Idaho. Washington Agr. Exp. Sta. Tech. Bull. 60. Washington State Univ.
Dealy, J.E. 1971. Habitat characteristics of the Silver Lake mule deer range. USDA Forest Serv. Res. Pap. PNW-125.

Drawe, D.L., J.B. Grumbles, and J.F. Hooper. 1975. Establishment of Russian wildrye on foothill ranges in Utah. J. Range Manage. 28:152154.

Driscoll, R.S. 1962. Characteristics of some ecosystems in the juniper zone in central Oregon. J. Range Manage. 15:347. (Abstract of Ph.D. diss.).

Driscoll, R.S. 1964. Vegetation-soil units in the central Oregon juniper zone. USDA Forest Serv. Res. Pap. PNW-19.

Dyrness, C.T., and C.T. Youngberg, 1966. Soil-vegetation relationships within the ponderosa pine type in the central Oregon pumice region. Ecology 47:122-138.

Eckert, R.E. 1958. Vegetation-soil relationships in some Artemisia types in northern Harney and Lake Counties, Oregon. J. Range Manage. 11:50. (Abstract of Ph.D. diss.).

Eichhorn, N.D., R.D. Rudd, and L.D. Calvin. 1961. Estimating dates for low temperatures in Oregon. Agr. Exp. Sta. Bull. 581. Oregon State Univ., Corvallis.

Franklin, J.F., and C.T. Dyrness. 1973. Natural vegetation of Oregon and Washington. USDA Forest Serv. Gen. Tech. Rep. PNW-8.

Frischknecht, N.C. 1951. Seedling emergence and survival of range grasses in central Utah. Agron. J. 43:177-182.

Game Division. 1967. Habitat improvement. p. 157-171. In: Annual report. Oregon State Game Commission. Portland.

Game Division. 1968. Habitat improvement. p. 163-183. In: Annual report. Oregon State Game Commission. Portland.

Game Division. 1969. Habitat improvement. p. 147-152. In: Annual report. Oregon State Game Commission. Portland.

Garrison, G.A., J.M. Skovlin, C.E. Poulton, and A.H. Winward. 1976. Northwest plant names and symbols for ecosystem inventory and analysis. Fourth edition. USDA Forest Serv. Gen. Tech. Rep. PNW-46.

Hafenrichter, A.L., J.L. Schwendiman, H.L. Hains, R.S. MacLauchlan, and H.W. Miller. 1968. Grass and legumes for soil conservation in the Pacific Northwest and Great Basin states. USDA Soil Conserv. Serv. Agr. Handbook 339.

Hampton, E.R. 1964. Geologic factors that control the occurrence and availability of ground water in the Fort Rock Basin, Lake County, Oregon. Geological Surv. Prof. Pap. 383-B. U.S. Gov. Print. Off., Washington, D.C.

Hubbard, R.L. 1960. Some results of bitterbrush reseeding in California. Proc. Amer. Soc. Range Manage. 13:17. Portland, Ore.

Hubbard, R.L., and H.R. Sanderson. 1961. When to plant bitterbrushspring or fall? USDA Forest Serv. Tech. Pap. PSW-64.

Hull, A.C., Jr. 1948. Depth, season and row spacing for planting grasses on southern Idaho rangelands. J. Amer. Soc. Agron. 40:960-969.

Hull, A.C., Jr. 1974. Seedling emergence and survival from different seasons and rates of seeding mountain rangelands. J. Range Manage. 27:302-304.

Hull, A.C., Jr., and C.J. Klomp. 1967. Thickening and spread of crested wheatgrass stands on southern Idaho ranges. J. Range Manage. 20:222227.

Levin, F.F., B. Gomm, and T.N. Johnsen, Jr. 1973. Cultural, seasonal, and site effects on pinyon-juniper rangeland plantings. J. Range Manage. 26:279-285.

Leckenby, D.A. 1968. Influences of plant communities on wintering mule deer. West. Proc. Annul. Conf. West. Assoc. State Game and Fish Com48:201-208.

Leckenby, D.A., and D.E. Toweill. 1978. Mule deer winter range ecology and management: seeded plant densities in the first, second, and fourth growing seasons after treatment of six juniper vegetation subtypes on a south-central Oregon mule deer range. Oregon Dep. Fish and Wildl. Final Rep. W-70-R-3 through W-70-R-7, Sub. B, Study II, Job. 8. Portland.

McGinnies, W.J. 1960. Effects of planting dates, seeding rates, and row spacing on range seeding results in western Colorado. J. Range Manage. 13:37-39.

Pacific Northwest River Basins Commission. 1969. Climatological handbook Columbia Basin States. Temperature. Vol. 1, Part A.

Pacific Northwest River Basins Commission. 1969h. Climatological handbook, Columbia Basin States. Temperature, Vol. 1, Part B.

Pacific Northwest River Basins Commission. 1969. Climatological handbook, Columbia Basin States. Precipitation. Vol. 2.

Plummer, A.P., D.R. Christensen, and S.B. Monson. 1968. Restoring big game range in Utah. Utah Div. of Fish and Game Publ. 68-3.

Roberts, R.W. 1975a. Silver Lake mule deer research: utilization of Nine Mile Ridge seeding by mule deer and compilation, analysis, interpretation, and publication of data acquired on Nine Mile Ridge seeding 
success. Oreg Dep. Fish and Wildl. Job Compl. Rep. W-70-R-1 through W-70-R-5, Sub. B, Study II, Jobs 4, 7. Portland.

Roberts, R.W. 1975b. Evaluating the impact of range treatment on vegetation. Wildl. Res. Rep. 7. Res. Div., Oregon Wildl. Comm., Corvallis. Schallig, W.H.C. 1971. Key to Silver Lake mule deer winter range plant communities. In: Mule deer winter range ecology and management: data analysis, interpretation, and publication. D.A. Leckenby and A.W. Adams. p. 13-24. Oregon Dep. Fish and Wildl. Job. Prog. Rep., Game Proj. W-70-R-1, Sub. B, Study I, Job 5-R, 1971. Portland.

Schwendiman, J.L. 1955. When, where and how to succeed with range seeding. Crops and Soils 7:9-11.
Siegel, S. 1956. Nonparametric statistics for the behavorial sciences. $312 \mathrm{p}$. McGraw-Hill Book Co., Inc., New York.

State Water Resources Board. 1969. Oregon's long-range requirements for water. General soil map report with irrigable areas, Goose and Summer Lake drainage basin. Append. 1-13.

Woolfolk, E.J. 1959. Semi-annual report to western browse restoration comittee. Calif. Proj. W-51-R, Game Range Restoration Seg. Western Browse Research 5:1-9.

Woolfolk, E.J. 1961. Semi-annual report to western browse restoration committee. Calif. Proj. W-51-R, Game Range Restoration Seg. Western Browse Research 6. 11 unnumbered leaves. 